UDC 633.16-155.9

631.415.2:631.452

Original research paper

doi: 10.5937/AASer1947041M

Acta Agriculturae Serbica, Vol. XXIV, 47(2019); 41-49

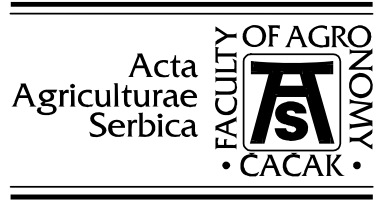

\title{
Assessment of the correlation between grain yield and its components in spring barley on an acidic soil
}

\author{
Milomirka Madić ${ }^{1}$, Desimir Knežević ${ }^{2}$, Dragan Đurović ${ }^{1}$, Aleksandar \\ Paunović ${ }^{1}$, Vladeta Stevović ${ }^{1}$, Dalibor Tomić ${ }^{1}$, Vera Đekić ${ }^{3}$ \\ ${ }^{1}$ University of Kragujevac, Faculty of Agronomy Čačak, Cara Dušana 34, Čačak, \\ Serbia \\ ${ }^{2}$ University of Priština (Kosovska Mitrovica), Faculty of Agriculture, Lešak, \\ Serbia \\ ${ }^{3}$ Small Grains Research Centre, Save Kovačevića 31, Kragujevac, Serbia \\ Corresponding author: mmadic@kg.ac.rs
}

\begin{abstract}
A field trial was conducted in 2016-2017 to determine the effect of different rates of mineral fertilisers, especially phosphorus, and lime on grain yield, yield components and their correlation in the spring barley cultivars 'Dunavac' and 'Novosadski 456' under dryland farming conditions at the experimental field of the Secondary School of Agriculture, Kraljevo. The experiment was performed on a very acidic soil $\left(\mathrm{pH}_{\mathrm{H} 2 \mathrm{O}}\right.$ 4.5), in a randomised block design with three replications. Grain yield, stem length, number of spikes $\mathrm{m}^{-2}$, spike length, number of grains per spike and grain weight per spike increased in response to mineral fertilisers and lime. Both cultivars performed better under mineral fertilisation and liming treatment than under increased phosphorus fertilisation, as the availability of macro- and micronutrients increased with increasing soil $\mathrm{pH}$ i.e. due to phosphorus immobilisation in the highly acidic environment. In general, significant positive correlations were observed among yield components, and between grain yield and its components. Grain yield was significantly positively correlated with number of spikes $\mathrm{m}^{-2}$, spike length, number of grains per spike and stem length. Correlations between grain yield and its components under diverse agroenvironmental conditions can guide the selection of cultural practices as well as the choice of cultivars for unfavourable growing conditions.
\end{abstract}

Keywords: barley, liming, mineral fertilisers, correlation, yield.

Received 19 May 2019 Accepted 27 June 2019 


\section{Introduction}

As one of the oldest plant species, barley has undergone substantial genetic change during its domestication. Over many thousand years of cultivation, the intended use of barley has moved from staple food to an important feed. Most of the world's barley is used for feed, followed by malting, $2-3 \%$ as food, and about $5 \%$ as a seed commodity (Ullrich, 2011). In the Republic of Serbia, according to the data from the Statistical Office of the Republic of Serbia for the period 20052015 (average values), barley was grown on 86,000 ha of land, with the total annual production of about $362,000 \mathrm{t}$ and the average annual yield of $3.8 \mathrm{t} \mathrm{ha}^{-1}$; in the last five years of the period, about $50 \%$ of the barley produced was used for livestock feed production and 50\% for malting. Barley grain quality is influenced by genetic and environmental factors, as well as by their interactions. Accordingly, in particular years, depending on grain nutrient levels, a cultivar can perform as either a malting or forage cultivar, which determines its intended use (Đekić et al., 2017). Breeding methods have resulted in genotypes (cultivars) which even in unfavourable environments, under appropriate cultural practices, have low protein contents, which make them suitable raw materials for the brewing industry (Pržulj et al. 2010). Abiotic stress factors (high and low temperatures, drought, acidic and saline soils) at different growth stages of barley are constraints to maximum grain yield potential. Stress duration and stress intensity vary with location, as well as with year at the same location. Individual stress rarely occurs, and plants are often subjected to a combination of stresses, which makes cultivar assessment complicated (Mohamadi et al., 2013). Today, barley breeding is mainly focused on creating genotypes with high yield potential, good adaptability and high performance in response to fertilisation (Pržulj et al. 2014). Lack of mineral fertilisers causes grain yield reductions in cereal crops; among small grain cereals, barley is most strongly affected, as its yield performance can be reduced by as much as $40 \%$ or above (Bogdanović et al., 1994). It is estimated that $30-40 \%$ of the world's arable land is acidic (von Uexkull and Mutert, 1995). According to the report on the status of soils (Ministry of the Environment and Urban Planning, 2009), Serbia is dominated by acidic soils i.e. $13 \%$ extremely acidic soils $(\mathrm{pH}<4.0), 17 \%$ very acidic soils ( $\mathrm{pH}$ 4.0-4.5), 30\% moderately acidic soils ( $\mathrm{pH} 4.5-5.5), 22 \%$ slightly acidic soils $(\mathrm{pH}$ 5.5-6.5) and $18 \%$ neutral or alkaline soils $(\mathrm{pH}>6.5)$. These data indicate that acidic soils account for $82 \%$ of the total agricultural land area in the Republic of Serbia. Pseudogleys cover 500,000 ha of land (Dugalić and Gajić, 2012).

The aim of this research was to determine the correlation between grain yield and its components, and the effect of mineral fertilisation and liming on grain yield and its components in two cultivars of spring barley grown on an acidic pseudogley. 


\section{Material and methods}

Research was conducted in 2016-2017 at the experimental field of the Secondary School of Agriculture and Chemistry in Kraljevo on an acidic soil $\left(\mathrm{pH}_{\mathrm{H} 2 \mathrm{O}} 4.5\right.$, humus $2.16 \%, \mathrm{P}_{2} \mathrm{O}_{5} 7.5 \mathrm{mg} 100^{-1} \mathrm{~g}$ and $\mathrm{K}_{2} \mathrm{O} 13.9 \mathrm{mg} 100^{-1} \mathrm{~g}$ soil) involving two cultivars of two-rowed spring malting barley ('Dunavac' and 'Novosadski 456') and different fertilisation treatments.

The treatments included complex NPK fertilisers $\left(\mathrm{N}_{8}: \mathrm{P}_{24}: \mathrm{K}_{16}\right)$, superphosphate $\left(17 \% \mathrm{P}_{2} \mathrm{O}_{5}\right)$ containing different amounts of phosphorus (I-0; II-60; III-140; IV-60 $\mathrm{kg} \mathrm{ha}^{-1}$ ) and a top dressing of ammonium nitrate $34.4 \% \mathrm{~N}\left(120 \mathrm{~kg} \mathrm{ha}^{-1}\right)$. Phosphorus, potassium and one third of nitrogen were incorporated during seedbed preparation. The remaining amount of nitrogen was used for top dressing at the beginning of spring. In addition to mineral fertilisers, "Njival $\mathrm{Ca}$ " lime $\left(98.5 \% \mathrm{CaCO}_{3}, 1 \%\right.$ $\mathrm{MgCO}_{3}$ ) was applied in treatment IV.

In both experimental years, crop rotation was used, with maize as the preceding crop. The trial was established in a randomised plot design with three replications and a plot size of $10 \mathrm{~m}^{2}$. Seeds were sown mechanically, at a spacing of $12 \mathrm{~cm}$ between rows and $3 \mathrm{~cm}$ within rows.

At full maturity, 30 plants were sampled from each plot for analysis of stem length $(\mathrm{cm})$, spike length $(\mathrm{cm})$, number of grains per spike and grain weight per spike (g). Number of spikes $/ \mathrm{m}^{-2}$ was determined at the end of the growing season during sampling by counting spikes per $\mathrm{m}^{-2}$. Grain yield was measured for each plot and converted to tonnes per hectare based on $14 \%$ grain moisture. Results were subjected to an analysis of variance using SAS/STAT software (SAS Institute, 2000). The correlation between yield and yield components was expressed by the simple correlation coefficient.

\section{Weather conditions}

The region of Kraljevo is characterised by continental climate and a nonuniform distribution of monthly precipitation. The average air temperatures during the growing seasons in 2016 and 2017 were higher by $1.5^{\circ} \mathrm{C}$ and $0.5{ }^{\circ} \mathrm{C}$, respectively, than the long-term average (Table 1).

The data on monthly precipitation indicate differences between the experimental period (2016-2017) and the long-term average (Tabe 1). In the 2016 growing season, the total sum of precipitation was above the long-term average, and its monthy distribution was rather non-uniform. High amounts of precipitation were recorded during grain filling, causing partial crop lodging. In June and July, precipitation totals were below the long-term average. In 2017, the total amount of precipitation was below the long-term average, the lowest at the beginning of the year, but gradually increasing during plant growth and development. 
Table 1. Mean monthly air temperatures $\left({ }^{\circ} \mathrm{C}\right)$

\begin{tabular}{|c|c|c|c|c|c|c|c|c|}
\hline Year & \multicolumn{8}{|c|}{ Month } \\
\hline & 1 & 2 & 3 & 4 & 5 & 6 & 7 & Average \\
\hline 2016 & -0.1 & 8.8 & 7.8 & 14.1 & 15.5 & 21.3 & 23.2 & 12.9 \\
\hline 2017 & -5 & 4.5 & 10.3 & 11.3 & 16.2 & 22.4 & 24 & 11.9 \\
\hline $\begin{array}{l}10 \text {-year } \\
\text { average }\end{array}$ & 0.1 & 2.2 & 6.6 & 11.7 & 16.5 & 19.7 & 21.8 & 11.4 \\
\hline & \multicolumn{7}{|c|}{ The amount of precipitation (mm) } & Total \\
\hline 2016 & 86.2 & 52.7 & 157.9 & 39.9 & 135.9 & 48.6 & 29.1 & 550.3 \\
\hline 2017 & 22.1 & 35.3 & 57.7 & 82.1 & 99.9 & 56.2 & 35.2 & 388.5 \\
\hline $\begin{array}{l}10 \text {-year } \\
\text { average }\end{array}$ & 44 & 42.8 & 44.7 & 65.1 & 74.9 & 86.5 & 72.3 & 430.3 \\
\hline
\end{tabular}

\section{Results and discussion}

The analysis of variance showed significant differences between cultivars and among fertilisation treatments for all analysed traits, except for grain weight per spike and grain yield in the first year (Table 2). Stem length in spring barley is not precisely defined. Mineral fertilisers, lime and increased phosphorus rates in both years led to a significant increase in stem length (treatments IV and III). The stem of barley has a weak mechanical tissue, and there is a selection tendency to create cultivars with shorter stems in order to eliminate plant lodging (Pržulj et al. 2010, Madić et al. 2016). Number of grains per spike and spike length were significantly greater in all treatments than in the unfertilised control. The designed ideotype of two-row barley has 40 grains per spike, but the value has not been reached yet (Denčić et al., 1992). This is also supported by the range of 15-25 in the present research and 20-25 in Dodig (2000). Spike length and number of spikelets per spike are largely governed by genotype i.e. they are affected by environmental factors to a very small degree (Kirchev et al., 2012).

Mineral fertilisers led to a significant increase in grain weight per spike (treatments II and III), which was highest in the treatment with mineral fertilisers and lime. Grain weight per spike is a yield component dependent on genotype (Knežević et al. 2019) as well as on nutrition, plant density, soil fertility and other factors in the agroecosystem during vegetative growth and development (Dimitrijević et al. 2009, Madić et al. 2018). Significant differences in barley grain weight depending on year and genotype were also reported by Đekić et al. (2017). 
Table 2. Means for stem length (StL), spike length (SpL), number of grains per spike (NGS), grain weight per spike (GWS), number of spikes $\mathrm{m}^{-2}(\mathrm{NS})$ and grain yield (GY kgha $\left.{ }^{-1}\right)$ in spring barley cultivars across fertilisation treatments in 2016 and 2017.

\begin{tabular}{|c|c|c|c|c|c|c|c|c|}
\hline \multicolumn{3}{|c|}{ Year } & StL & $\mathrm{SpL}$ & NGS & GWS & NS & GY \\
\hline & \multirow{2}{*}{$\begin{array}{l}\text { Cultivars } \\
\text { (A) }\end{array}$} & Dunavac & $78.8 \mathrm{a}$ & $10.1 \mathrm{a}$ & $23.7 \mathrm{a}$ & 1.01 & $563 a$ & 3299 \\
\hline & & NS456 & $75.2 b$ & $8.7 b$ & $19.6 \mathrm{~b}$ & 0.98 & $412 b$ & 3077 \\
\hline 2 & & & & & & & & \\
\hline 0 & \multirow{2}{*}{ Treatment } & I & $67.4 b$ & $6.7 \mathrm{~b}$ & $18.5 \mathrm{~b}$ & $0.67 \mathrm{c}$ & $293 c$ & $1090 \mathrm{~d}$ \\
\hline 1 & & II & $76.5 \mathrm{ab}$ & $8.9 a$ & $22.5 \mathrm{a}$ & $1.19 \mathrm{~b}$ & $410 \mathrm{~b}$ & $3065 c$ \\
\hline \multirow[t]{2}{*}{6} & \multirow[t]{2}{*}{ (B) } & III & $82.8 \mathrm{a}$ & $9.5 \mathrm{a}$ & $22.7 \mathrm{a}$ & $1.21 \mathrm{~b}$ & $586 \mathrm{~b}$ & $3815 b$ \\
\hline & & IV & $81.9 \mathrm{a}$ & $9.3 \mathrm{a}$ & $23.1 \mathrm{a}$ & $1.34 \mathrm{a}$ & $682 a$ & $4825 a$ \\
\hline & \multirow[t]{3}{*}{ ANOVA } & A & $* *$ & $* *$ & $* *$ & ns & $* *$ & ns \\
\hline & & B & * & $* *$ & $* *$ & $* *$ & $* *$ & $* *$ \\
\hline & & $\mathrm{AB}$ & ns & $* *$ & ns & ns & ns & ns \\
\hline & \multirow{2}{*}{$\begin{array}{l}\text { Cultivars } \\
\text { (A) }\end{array}$} & Dunavac & $73.3 \mathrm{a}$ & $10.2 \mathrm{a}$ & $24.6 \mathrm{a}$ & 1.07 & $587 \mathrm{a}$ & $3388 \mathrm{a}$ \\
\hline & & NS456 & $65.1 \mathrm{~b}$ & $7.8 \mathrm{~b}$ & $19.2 \mathrm{~b}$ & 1.02 & $465 b$ & $2771 b$ \\
\hline \multicolumn{9}{|l|}{2} \\
\hline 0 & \multirow[t]{2}{*}{ Treatment } & I & $57.6 \mathrm{c}$ & $7.2 b$ & $15.2 b$ & $1.06 \mathrm{c}$ & $363 c$ & $2109 d$ \\
\hline 1 & & II & $70.7 b$ & $9.3 \mathrm{a}$ & $21.8 \mathrm{a}$ & $1.14 \mathrm{~b}$ & $399 b$ & $3678 \mathrm{c}$ \\
\hline \multirow[t]{5}{*}{7} & \multirow[t]{2}{*}{ (B) } & III & $73.1 \mathrm{a}$ & $9.7 \mathrm{a}$ & $23.6 \mathrm{a}$ & $1.20 \mathrm{ab}$ & $489 b$ & $4713 b$ \\
\hline & & IV & $75.2 \mathrm{a}$ & $9.6 \mathrm{a}$ & $24.9 \mathrm{a}$ & $1.38 \mathrm{a}$ & $599 a$ & $5647 \mathrm{a}$ \\
\hline & \multirow[t]{3}{*}{ ANOVA } & A & $* *$ & $* *$ & $* *$ & ns & $* *$ & $* *$ \\
\hline & & B & ** & $* *$ & $* *$ & * & $* *$ & $* *$ \\
\hline & & $\mathrm{AB}$ & ns & $* *$ & $\mathrm{~ns}$ & $* *$ & $\mathrm{~ns}$ & ns \\
\hline
\end{tabular}

Means followed by the same lowercase letters in cultivar and treatment columns in the same year are not significantly different at the $95 \%$ level according to LSD test

** $\mathrm{F}$-test significant at $0.01 ; * \mathrm{~F}$-test significant at 0.05 ; ns non-significant

Regardless of fertiliser treatment, in both experimental years, the performance of 'Dunavac' was significantly better in all traits, except grain yield and grain weight per spike. Regardless of cultivar, differences in grain yield among treatments were significant in both years: the lowest yield was obtained in the unfertilised control, and the highest after treatment with mineral fertilisers and lime (treatment IV). The highest increase in grain yield was in 2016 after 
NP1K treatment (treatment II), almost three times relative to the control, whereas the increase in 2017 was $42.7 \%$. As P rates increased (treatments II-III), grain yield increased by $19.7 \%$ in 2016 and $21.9 \%$ in 2017 , whereas the increase under mineral fertilisation and liming treatments (II-IV) was $36.5 \%$ in the first year and $24.2 \%$ in the second. Barley cultivars ('Dunavac' and 'NS 456') had better yield responses to lime than increased $\mathrm{P}$ rates, as the availability of macro- and microelements increased with increasing soil $\mathrm{pH}$ i.e. due to $\mathrm{P}$ immobilisation in the very acid environment.

Table 3. Coefficients of correlation between grain yield and grain components in spring barley

\begin{tabular}{lcccccc}
\hline Yield parameters & $\begin{array}{c}\text { Stem } \\
\text { length } \\
(\mathrm{cm})\end{array}$ & $\begin{array}{c}\text { Spike } \\
\text { length } \\
(\mathrm{cm})\end{array}$ & $\begin{array}{c}\text { Number } \\
\text { of grains } \\
\text { per spike }\end{array}$ & $\begin{array}{c}\text { Grain } \\
\text { weight } \\
\text { per spike } \\
(\mathrm{g})\end{array}$ & $\begin{array}{c}\text { Number } \\
\text { of } \\
\text { spikes } \\
\text { per m }\end{array}$ & $\begin{array}{c}\text { Grain } \\
\text { yield } \\
\left(\mathrm{kg} \mathrm{ha}^{-1}\right)\end{array}$ \\
\hline $\begin{array}{l}\text { Grain yield }\left(\mathrm{kg} \mathrm{ha}^{-1}\right) \\
\text { Number of spikes }^{2}\end{array}$ & $0.58^{* *}$ & $0.65^{* *}$ & $0.61^{* *}$ & $0.18^{*}$ & $0.73^{* *}$ & \\
$\begin{array}{l}\text { per m } \\
\text { Grain weight per } \\
\text { spike (g) }\end{array}$ & $0.41^{* *}$ & $0.17^{*}$ & $0.06^{\mathrm{ns}}$ & $-0.21^{* *}$ & \\
$\begin{array}{l}\text { Number of grains } \\
\text { per spike }\end{array}$ & $0.09^{\mathrm{ns}}$ & $0.05^{\mathrm{ns}}$ & $-0.19^{* *}$ & & \\
Spike length (cm) & $0.53^{* *}$ & $0.81^{* *}$ & & & & \\
\end{tabular}

* NS - non-significant; * significant at the 0.05 level; ** significant at the 0.01 level.

The correlation analysis showed a positive correlation between grain yield and number of spikes per unit area $(\mathrm{r}=0.73)$, spike length $(\mathrm{r}=0.65)$, number of grains per spike $(\mathrm{r}=0.61)$, stem length $(\mathrm{r}=0.58)$ and grain weight per spike $(\mathrm{r}=0.18)$ (Table 3). Significant negative coefficients of correlation were determined between grain weight per spike and number of grains per spike, and number of spikes per $\mathrm{m}^{2}$ and grain weight per spike. A somewhat stronger correlation between grain yield and yield components was found by Moreno et al. (2003), who reported a strong correlation between grain yield and: number of spikes $(\mathrm{r}=0.91)$, number of grains per spike $(\mathrm{r}=0.69)$ and 1,000 -grain weight $(\mathrm{r}=$ 0.45). Paunovic et al. (2007) observed that grain yield was positively correlated with number of spikes $(\mathrm{r}=0.63)$, but negatively correlated with spike length $(\mathrm{r}=-$ 0.63 ), and Đekić et al. (2019) determined that grain yield positively correlated with stem length $(\mathrm{r}=0.57)$ and 1,000 grain weight $(\mathrm{r}=0.31)$. Grain yield relies on well-balanced yield components; therefore, an increase in one component often leads to a decrease in another, with maximum yield generated through the most favourable balance, as shown by the negative correlation between number of 
grains and grain weight per spike, and between number of spikes $\mathrm{m}^{-2}$ and grain weight per spike. Environmental factors affect the expression of yield components, leading to changes in yield performance and the relative contributions of individual components to overall yield (Wallace and Zobel, 1994).

\section{Conclusion}

The analysis of variance of two spring barley genotypes indicated significant differences in the studied traits. Mineral fertilisers and lime had a significant effect on these traits in both barley cultivars. In response to liming, the soil $\mathrm{pH}$ and, hence, the availability of macro- and microelements, particularly phosphorus, increased. Grain yield showed significant positive correlations with number of spikes $\mathrm{m}^{-2}$, spike length, and number of grains per spike. Grain yield relies on the balance among yield components, with maximum yield generated through the most favourable balance, as shown by the negative correlation between number of grains and grain weight per spike, and between number of spikes $\mathrm{m}^{-2}$ and grain weight per spike. Correlations between grain yield and yield components under diverse agroenvironmental conditions can guide the selection of cultural practices, as well as the choice of cultivars for unfavourable production conditions.

\section{Acknowledgement}

This research is financially supported by the Ministry of Education, Science and Technological Development, Republic of Serbia. This work is part of the research Projects Ref. Nos. TR 31054 and TR 31092.

\section{References}

AgroChart (2013). Serbia. Grain and Feed Annual http://www.agrochart.com/en/news/news/030513/serbia-grain-and-feedannual- mar$2013 /$

Bogdanović D., Ćirović M., Ubavić M. (1994): Racionalno đubrenje semenskog kukuruza. Monografija, Poljoprivredni fakultet Novi Sad, VII: 73-89.

Đekić V., Milivojević J., Madić M., Popović V., Branković S., Perišić V., Terzić D., (2019): Grain yield and quality of two-row winter barley cultivars on an acid soil. Journal of Central European Agriculture, 20 (1): 238-250.

Đekić V., Popović V., Branković S.,Terzić D., Đurić N. (2017): Yield components and grain yield of winter barley. Agriculture and Forestry, 63 (1): 179-185.

Denčić S., Mikić K., Momčilović V. (1992): Rezultati rada na genetici i oplemenjivanju ječma. Lazić, V. (ed.) Pivski ječam i slad. Monografija: 52-64. 
Dimitrijević M., Petrović S., Mladenov N., Belić M., Hristov N., Banjac B., Vukosavljev M. (2009): Phenotypic reaction of wheat grown on different soil types. Genetika, 41 (2): $169-177$.

Dodig D. (2000) Morfološke i produktivne osobine hibrida dvoredog i šestoredog ječma u F4 i F5 generaciji. Master thesis. Beograd: Univerzitet u Beogradu, Poljoprivredni fakultet.

Dugalić G., Gajić B. (2012): Pedologija. Univerzitet u Kragujevcu, Agronomski fakultet u Čačku.

Knezevic D., Paunović A., Zečević V., Urošević D., Kondic D., Mićanović D., Živić. J., Madić M., Đurović V., Srdic S., Kovačević (2019): Varijabilnost mase klasa sorti ozime pšenice (Triticum aestivum L.). XXIV Savetovanje o Biotehnologiji sa međunarodnim učešćem, Čačak, 15-16. mart, Zbornik radova 1: 37-45.

Kirchev H., Delibaltova V, Yanchev I., Zheliazkov I. (2012): Comparative investigation of ryetype triticale varieties, grown in the agroecological conditions of Thrace valley. Bulgarian Journal of Agricultural Science, 18 (5): 696-700.

Madić M., Knežević D., A. Paunović, Đurović D. (2016): Plant height and internode length as components of lodging resistance in barley. Acta Agriculturae Serbica, XXI (42): 99-106.

Madić M., Paunović A., Đurović D., Marković G., Knežević D., Jelić M., Stupar V. (2018): Grain yield and its component in triticale grown on a pseudogley soil. Journal of Central European Agriculture, 19 (1): 184-193.

Mohamadi M., Karimizade R., Noorinia A.A. (2013): Analysis of yield stability in multienvironment trials of barley (Hordeum vulgare L.) genotypes using AMMI model. Current Opinion in Agriculture, 2 (1): 20-24.

Moreno A., Moreno M.M., Ribas F., Cabello M. J. (2003): Influence of nitrogen fertilizer on grain yield of barley (Hordeum vulgare L.) under irrigated conditions. Spanish Journal of Agricuture Research, 1 (1): 91-100.

Paunović A., Madić M., Knežević D., Bokan N. (2007): Sowing density and nitrogen fertilization influences on yield components of barley. Cereal Research Communications, 35 (2): 901-904.

Pržulj N., Momčilović V., Nožinić M., Jestrović Z., Pavlović M., Obrović B. (2010): Importance and breeding of barley and oats. Ratarstvo i povrtarstvo, 47 (1): 33-42.

Pržulj N., Momcilovic V., Simic J., Mirosavljevic M. (2014): Effect of year and variety on barley quality. Genetika, 46 (1): 59-73.

SAS/STAT (2000): User's guide, Version 9.1.3. SAS Institute Inc.

Ullrich S.E. (2011): Significance, Adaptation, Production and Trade of Barley. Book chapter in Barley Production, Improvement and Uses, Edited by Steven E. Ullrich, Blackwell Publishing Ltd: 3- 14.

Wallace D.H., Zobel R.W. (1994): Whole-system research complements reductive research, In: Pessarakli, M. (Ed.), Handbook of Plant and Crop Physiology. Marcel Dekker, New York: 833-848.

Von Uexkull H.R., Murtert E. (1995): Global extent, development and economic impact of acid soils. Plant and Soil, 171: 1-15. 


\title{
KORELACIONA ZAVISNOST PRINOSA ZRNA I KOMPONENTI PRINOSA PROLEĆNOG JEČMA GAJENOG NA KISELOM ZEMLJIŠTU
}

\author{
Milomirka Madić ${ }^{1}$, Desimir Knežević ${ }^{2}$ Dragan Đurović1, Aleksandar \\ Paunović ${ }^{1}$, Vladeta Stevović ${ }^{1}$, Dalibor Tomić ${ }^{1}$, Vera Đekić ${ }^{3}$ \\ ${ }^{1}$ Univerzitet u Kragujevcu, Agronomski fakultet u Čačaku, Cara Dušana 34, \\ Čačak, Srbija \\ ${ }^{2}$ Univerzitet u Prištini (Kosovska Mitrovica), Poljoprivredni fakultet, Lešak, \\ Srbija \\ ${ }^{3}$ Centar za strna žita Kragujevac, Save Kovačevića 31, Kragujevac, Srbija
}

\section{Rezime}

Poljski ogledi sa dve sorte prolećnog ječma „Dunavac” i „Novosadski 456” postavljeni su tokom 2016-2017. godine, sa ciljem da se analizira uticaj kalcizacije i različitih količina mineralnih đubriva, naročito fosfora na komponente prinosa i prinos zrna, kao i da se utvrdi korelaciona zavisnost između prinosa zrna i komponenti prinosa. Ogled je postavljen na kiselom zemljištu $\left(\mathrm{pH}_{\mathrm{H} 2 \mathrm{O}} 4,5\right)$ na eksperimentalnom polju Srednje poljoprivredne škole $\mathrm{u}$ Kraljevu po slučajnom blok sistemu u tri ponavljanja. Mineralna ishrana i kalcizacija su uticali na prinos zrna i komponente prinosa kod obe sorte ječma. Pored toga, sorte su bolje reagovale na kalcizaciju u odnosu na povećane količine fosfora, što se može povezati sa olakšanim korišćenjem makro i mikroelemenata pri povećanju $\mathrm{pH}$ zemljišta, tj. imobilizacijom fosfora $\mathrm{u}$ kiseloj sredini. Značajne pozitivne korelacije utvrđene su između prinosa zrna i broja klasova $\mathrm{m}^{-2}$, prinosa zrna i dužine klasa, kao i prinosa zrna i broja zrna po klasu. Prinos zrna se ostvaruje kao balans između komponenti prinosa, tako da je maksimalni prinos realizacija najpovoljnijeg balansa između komponenti, što pokazuje negativna korelacija između broja zrna i mase zrna po klasu kao i broja klasova $\mathrm{m}^{-2}$ i mase zrna po klasu. Međuzavisnosti prinosa zrna i komponenti prinosa $u$ različitim agroekološkim uslovima, pored toga što upućuju na izbor odgovarajućih agrotehničkih mera, istovremeno mogu poslužiti i kao selekcioni kriterijumi pri izboru sorti za manje povoljne proizvodne uslove.

Ključne reči: ječam, kalcizacija, mineralna đubriva, koralacija, prinos. 